\title{
TECHNOLOGICAL ENTREPRENEURSHIP IN EMERGING SOCIETIES: DOES HERITAGE REALLY MATTER?
}

\author{
F.J. Lotz and A.J. Buys \\ Department of Engineering and Technology Management \\ University of Pretoria, South Africa \\ frans.lotz@shaw.ca, andre.buys@up.ac.za
}

\begin{abstract}
A fundamental topic for researchers in entrepreneurship in recent times has been the question about the extent to which heritage factors such as birth order, family interaction, social class, economic circumstances, and society's views influence entrepreneurial behaviour. The present body of knowledge was mainly derived from studies conducted on single dominant culture groups in the developed world. While there is strong evidence in the literature to suggest that heritage plays a role in the development of the technological entrepreneur - either through environmental influences or genetic inheritance - the question remains: how strong in fact is this heritage influence in societies that are different from those in the previous studies? Research conducted by the University of Pretoria on technological entrepreneurs in the province of KwaZulu-Natal not only confirms certain existing models, but also provides new insight into the influences of heritage in a multi-cultural society and economically emerging region.
\end{abstract}

\section{OPSOMMING}

'n Fundamentele onderwerp vir navorsers in ondernemerskap is tans die vraag in watter mate herkomsfaktore soos geboortevolgorde, familieinteraksie, sosiale klas, ekonomiese omstandighede, en die sieninge van die samelewing ondernemerskapsgedrag beïnvloed. Die huidige stand van kennis was hoofsaaklik afgelei uit studies van enkel dominante kultuurgroepe in die ontwikkelde wêreld. Terwyl daar sterk bewyse in die literatuur is wat suggereer dat herkoms 'n belangrike rol in die ontwikkeling van tegnologiese ondernemers speel, hetsy deur omgewingsinvloede of genetiese erfenis, bly die vraag steeds: hoe sterk is die herkomsinvloed werklik in samelewings wat verskil van dié in vorige studies? Navorsing is by die Universiteit van Pretoria gedoen oor tegnologiese ondernemers in die Kwa-Zoeloe-Natal provinsie wat nie net sekere bestaande modelle bevestig nie, maar ook nuwe insigte bring van herkomsinvloede in 'n multi-kulturele samelewing en ekonomies ontwikkelende gebied. 


\section{INTRODUCTION}

A basic point of departure in the study of entrepreneurship is whether entrepreneurship is a universal feature of human nature that is fundamentally common to all societies, irrespective of their composition or level of economic development. Following this is the question: To what extent do local and cultural factors influence the practice and fundamental principles of entrepreneurship in these societies? In the following remarks, Wickham [1] expresses a strong view that entrepreneurship is in fact universal for all societies:

"This is not to say that local and cultural factors are not important or that differing economic conditions around the world do not impact specifically on entrepreneurial activity, but that they represent a surface veneer on a fundamentally common process."

A second fundamental principle to consider when positioning oneself in the entrepreneurship discipline is to what extent personality is a determinant of entrepreneurial inclination or success. Again Wickham [1] supports the notion that psychology does contribute to the body of knowledge in entrepreneurship, but rejects "the claim that 'personality' is a prior, determining and necessary precursor to effective entrepreneurship”.

Several aspects of the entrepreneur's background have been explored extensively by researchers. Hisrich, Peters and Shepherd [2] single out areas such as childhood family environment, education, personal values, and age and work history. The childhood family environment is of particular interest within the framework of this paper. Specific topics where research results have been published include birth order, parents' occupation(s) and social status, and the relationship with parents. The present theory framework is explored in order to establish the extent to which heritage influences entrepreneurial behaviour within a given set of circumstances.

\section{PRESENT BODY OF KNOWLEDGE}

The debate about entrepreneurial development focuses on several models and theories that have been proposed by leading researchers in the field. Before reviewing some of these theories, it is appropriate to obtain an oversight of the topic. Wickham [1] distinguishes between the following three factors that affect the entrepreneur's development:

- Innate factors such as intelligence, drive, and personality;

- Acquired features such as education, experience, and mentoring;

- Social factors like birth order, family interaction, social class, economic circumstances, and society's influence.

On the other hand, Bolton and Thompson [3] group the entrepreneurship domain into three sections:

- What entrepreneurs are like - the personality factors; 
- Where entrepreneurs come from - the environmental factors;

- What entrepreneurs do - the action factors.

\subsection{The 'made' or 'born' debate}

Ever since the early scholars of entrepreneurship such as Mill, Weber, Schumpeter and McClelland [4] studied the behaviour and personality traits of entrepreneurs, the "made" or "born" debate has been rooted in the discipline. It is generally accepted that personality traits are determined by two dominant factors: genetic inheritance and environmental influences. The ratio of contribution by genetic versus environment reportedly varies from 75:25 (according to Woods) to 40:60 (according to Whybrow) [3]. Whichever ratio is representative, the fact remains that environmental influences are important parameters that can be influenced during the development of certain personality attributes associated with entrepreneurship. Hornaday, as cited by Bolton et al [3], proposed a list of forty-two characteristics that included such traits as perseverance, ability to take calculated risks, the need to achieve, creativity, integrity, and independence. Whether these characteristics have been influenced by the environment or have been genetically inherited is not relevant. What is important is the notion that entrepreneurs are both 'made' and 'born'. Timmons et al [4] propose the following reality in arguing against certain myths about entrepreneurs:

"While entrepreneurs are born with certain native intelligence, a flair for creating, and energy, these talents by themselves are like unmolded clay or an unpainted canvas. The making of an entrepreneur occurs by accumulating the relevant skills, know-how, experience, and contacts over a period of years and includes large doses of self-development. The creative capacity to envision and then pursue an opportunity is a direct descendent of at least 10 or more years of experience that lead to pattern recognition."

This paper focuses on both the environmental influences on technological entrepreneurs during their early development, and - to a lesser extent - their genetic heritage.

\subsection{The Roberts model}

The concept of 'entrepreneurial heritage' was developed by Edward B. Roberts [5] to describe the importance of the entrepreneur's family background. Factors such as growing-up experiences, the family's work ethic, religion, father's occupation, family size, position as a child in the family, and family income were included in the 'heritage'. He studied several 'high-tech' entrepreneurs along Route 128 in Boston, Massachusetts, and came to the following conclusions regarding entrepreneurial heritage:

- Entrepreneurs are very likely to have had self-employed fathers;

- First-born sons are not more likely than their siblings to become high-technology entrepreneurs; 
- Entrepreneurs are not all alike: they display wide ranges of personalities, motivations, and goals for starting new enterprises;

- Family background has no impact on entrepreneurial success: successful entrepreneurs are made, not born!

He proposed the model for technological entrepreneurship development shown in Figure 1.

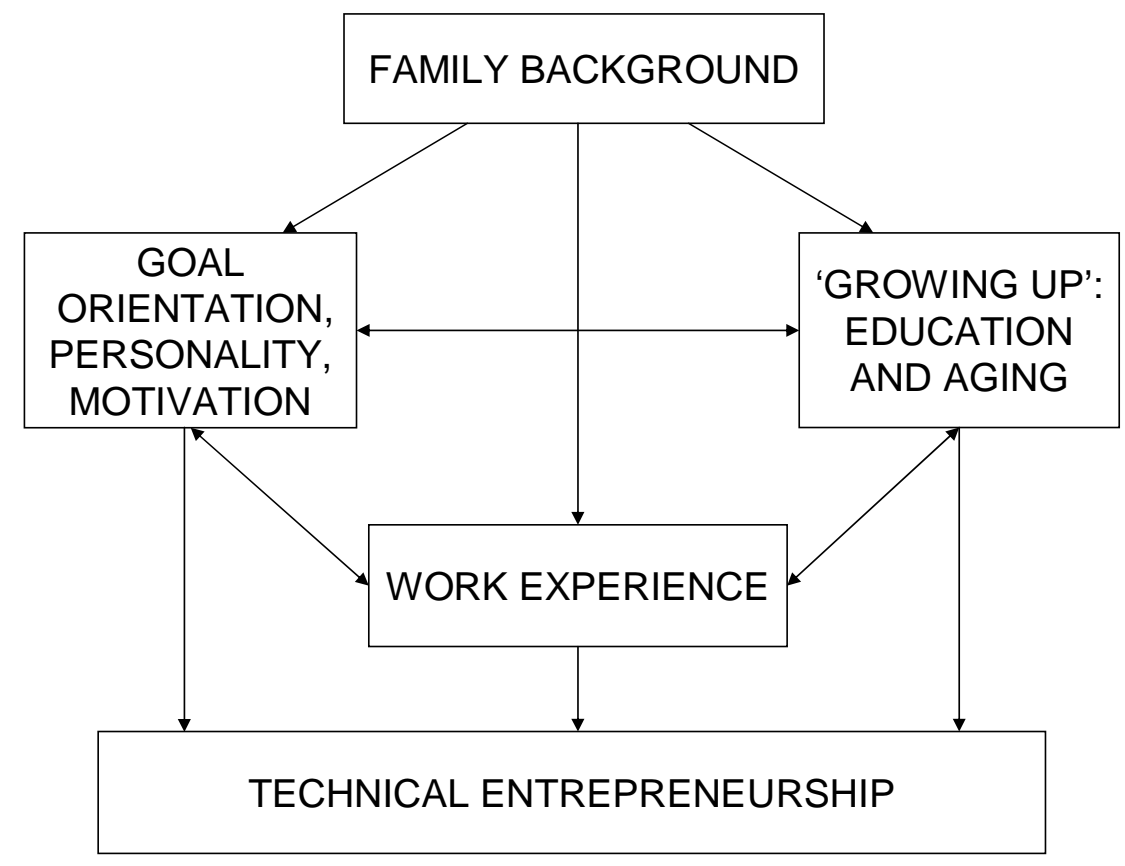

Figure 1: Entrepreneur development model by Roberts [5]

\subsection{The Drucker views}

Peter F. Drucker [6] explored the entrepreneur as an 'innovator'. His persistent view was that up to the early 1980s, most prominent businesses in the Western World "...believed that innovation is inspiration and entrepreneurship good luck". His argument was that successful Japanese firms re-organized their innovative and entrepreneurial activities successfully in the early 1990s to establish the principle that innovation, like entrepreneurship, is a practice with simple purposeful and systematic rules. They are disciplines in their own right that can be mastered through learning, practice, and hard work. His views are supported by Kuratko and Hodgetts [7] and Hornsby and Kuratko [8] in their contemporary approach to the subject.

\subsection{Other perspectives}

The views of the following researchers and authors are noteworthy:

- Bolton et al [3] argued that the three factors of entrepreneurship - personality, environment, and action - are insufficient to understand entrepreneurship fully and to 'spot potential winners'. They developed a tripartite approach whereby 
the entrepreneur's abilities are presented in three elements: talent, temperament, and technique. These elements are shown schematically in Figure 2.

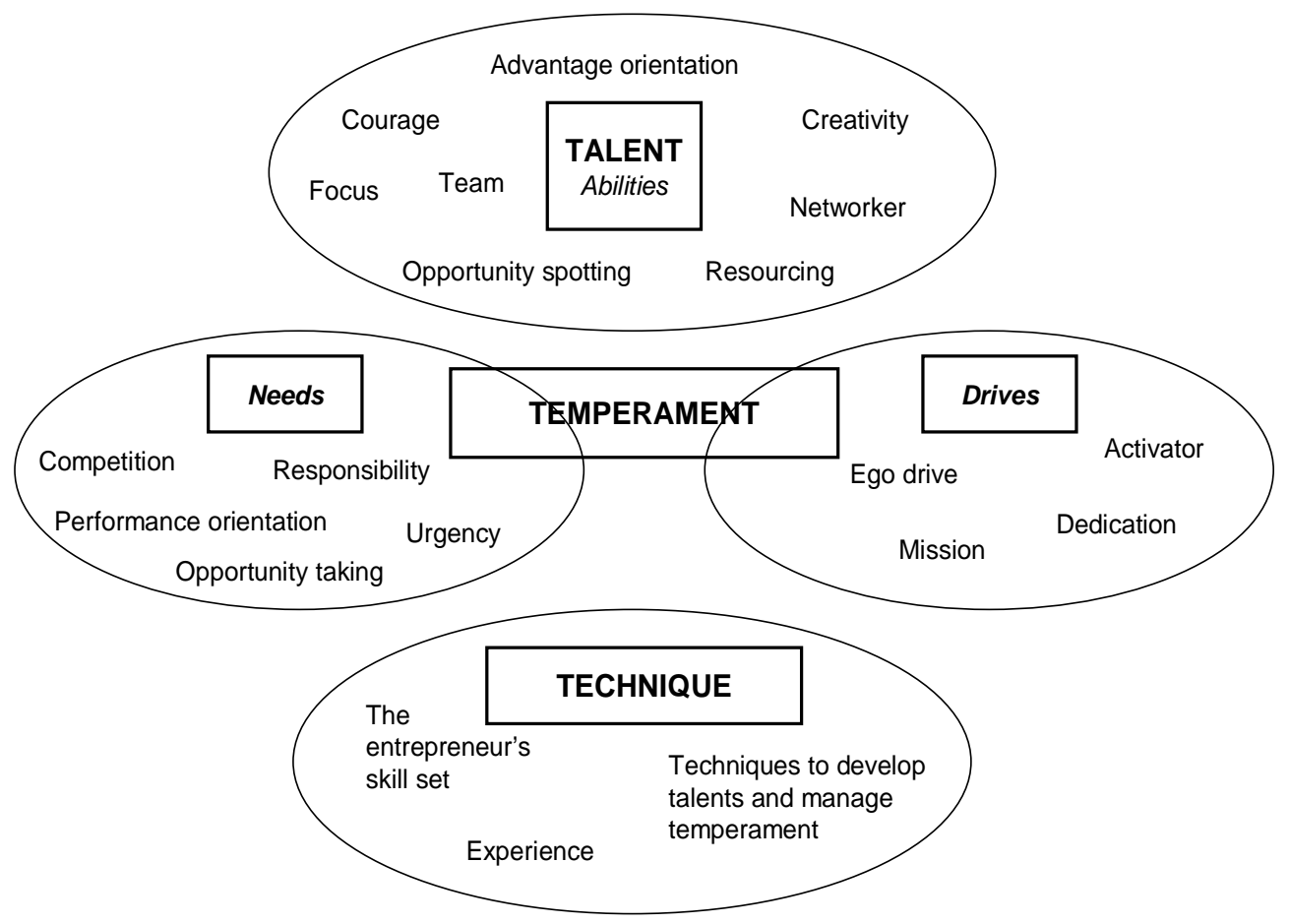

Figure 2: Talent, temperament and technique model of Bolton and Thompson [3]

- $\quad$ Other researchers such as Timmons et al [4] refer to the 'entrepreneurial roots' in which parents provide the role models for the potential entrepreneurial child;

- Hisrich and Brush's study of 500 women entrepreneurs (as cited by Bolton et al [3]) found that the majority had fathers who were self-employed. They also found $50 \%$ to be firstborn;

- In a Canadian study of participants in an entrepreneurship program (cited by Bolton et al [3]), Brockhouse and Horwitz found "that the characteristic most frequently associated with the entrepreneurial group was being the oldest child in the family".

- $\quad$ The work of Henning and Jardim (as cited by Rwigema and Venter [9]) suggests that female executives tend to be firstborn and that firstborn children tend to receive special attention, resulting in greater self-confidence and spurring entrepreneurship;

- Marlow and Patton [10] explore the debate about the effect of gender characterization upon female entrepreneurs, using the specific issue of both formal and informal sources of business funding. They found support for the notion that women entrepreneurs entering self-employment are disadvantaged by their gender; 
- $\quad$ Hisrich et al [2] report that having a father or mother who is self-employed provides a strong inspiration for the entrepreneur, as the independent nature and flexibility of self-employment is engrained at an early age. They conclude as follows on the firstborn topic:

"In many studies of male and female entrepreneurs, the firstborn effect has not been present. Since the relationship to entrepreneurship has not been established, further research on the firstborn effect is still needed to determine whether it really does have an effect on an individual becoming an entrepreneur".

- Cultural and macro-environmental influences on the entrepreneurial behaviour of population groups in developing countries have been studied by researchers such as Kunango and Themba et al, as cited by Nieuwenhuizen [11]. Verheul, Van Stel and Thurik [12] studied environmental effects such as unemployment, informal sector, former communist country, and informal venture capital on male and female entrepreneurs at country level. They found the effect of unemployment is smaller for women, and the effect of life satisfaction on entrepreneurial activity is positive for women and non-existent for men;

- $\quad$ On the sociological aspect of entrepreneurship, Zafirovski [13] concludes as follows:

“...the profit motive of entrepreneurship appears as a culture-specific, institutional incentive, not as an expression of some inborn propensity to profiteering. For human motives, preferences and values cannot be taken as parametric, homogeneous and exogenous to society, but as variable, heterogeneous and endogenous to it and its culture and institutions."

- In a cross-national study of culture and economic activities, Frederking [14] found that structural factors such as immigration laws, housing and education policies affect the relevance of culture in entrepreneurship;

- In the South African context, the remarks of Van Aardt \& Van Aardt (as cited by Rwigema et al [9]) are perhaps an accurate summary:

"In general, South Africans are not socialized or educated to become entrepreneurs, but to enter the labour market as employees. In becoming employees, they become consumers of existing jobs instead of creators of new jobs...The trend of people being socialized and educated to become employees appears to be especially true in respect of Africans..."

While there is strong evidence in the literature that heritage plays a role in the development of the technological entrepreneur, either through environmental influences or genetic inheritance, the question remains: how strong in fact is this heritage influence in societies that are different from those in the previous studies? 


\section{RESEARCH METHODOLOGY}

\subsection{Research design}

Research has been conducted by the University of Pretoria on technological entrepreneurs in South Africa. As the survey samples of existing studies functioned mainly in a single dominant culture society and a developed economy, it was critical that a study population from a multi-cultural society in an emerging economy be selected. The study population therefore consists of entrepreneurs who have founded and successfully operated a business with a significant technological component in its final product or service, from a multi-cultural developing region. Consideration was given to several research methodologies, and it was decided to gather data through population sampling.

The first step in the identification of a sample frame was to select an emerging economic region with a representative profile. The critical factors used in this first selection process were geography, economic activities, and cultural composition. The Province of KwaZulu-Natal, one of nine provinces of South Africa and situated on the east coast, was selected as the sample frame region.

The second step was to identify technological enterprises within the region. A commercial database that listed approximately 500,000 data entries of businesses in Southern Africa was used for this purpose [15]. A sample frame of 2,687 technology based businesses in KwaZulu-Natal was extracted from the database in the following three categories: Manufacturing, technical services, and technical general (which included mining, chemical, and industrial sectors).

The third step was to identify which of the original entrepreneurs were still active in the operations of the sample frame businesses, or could be located by recent contact detail. A survey questionnaire was developed to request, inter alia, personal and background information about the entrepreneur such as age, religion, gender, position in the family, home language, training, level of education, as well as the development of their entrepreneurial capabilities. Further information about the new venture creation process, and the development into and the performance of the mature business was gathered.

\subsection{Data collection}

The sample frame of 2,687 businesses was systematically contacted by telephone, email, or visits to their premises by research assistants. Their first task was to ascertain which of the original business founders (if any) were either (a) still in office participating in business activities, or (b) could be located by means of recent contact detail. Once this was established, personal contact was made with the founders and the questionnaire delivered to each of them by one of the following means:

- $\quad$ By hand for completion and collection later;

- $\quad$ By hand for completion during an appointment;

- $\quad$ By facsimile for completion and returning by facsimile; or 
- $\quad$ By e-mail for completion and returning by e-mail or facsimile.

A total of 210 completed questionnaires were collected in this manner and analysed statistically. The location, sector, and racial profiles of the survey sample that completed questionnaires are as follows:

- $\quad$ Metropolitan: 57.9\%; non-metropolitan: 42.1\%;

- Manufacturing: 45.4\%; Technical services: 30\%; and Technical general: 24.6\%;

- $\quad$ Indian: 54.8\%; White: 39.5\%; and Black and other: 5.7\%.

\subsection{Statistical analysis}

The data was analyzed using SAS software, and the following statistical techniques were used in the analysis [16]:

- $\quad$ Frequency distribution;

- Model fitting through stepwise multiple linear regression where populations follow the normal distribution; and

- $\quad$ Model fitting through stepwise logistic regression (Chi-square goodness-of-fit test) where the distribution of populations is categorical.

Only correlations with probabilities lower than 5\% $(\mathrm{P}<0.05)$ are shown in the significance of test tables, while the stepwise model building process and final model only utilised probabilities lower than $20 \%(\mathrm{P}<0.20)$.

\section{RESULTS}

\subsection{Frequency distribution}

The means and frequency distributions of the survey sample respondents are given in Table 1, indicating the mean plus standard deviation or the percentage representation of the respondents.

\subsection{Model building}

The correlations between various independent variables and selected dependent variables of the entrepreneur were investigated by doing stepwise regression analysis. The independent variables were classified into heritage factors as a result of growing-up experience (referred to as growing-up heritage) and cultural influences (referred to as cultural heritage).

The relationships between these independent variables and several defined variables of the entrepreneur's personal profile, the new venture creation process, and the success of the mature business were tested for significance. Three independent variables emerged in the stepwise regression analyses, which are classified as growing-up heritage. They are 1) age when first introduced to entrepreneurship, 2) whether father and mother were self-employed, and 3) magnitude of family income 


\begin{tabular}{|c|c|c|c|}
\hline Variable & Category & $\begin{array}{c}\text { Mean or } \\
\text { frequency } \\
\text { distribution }\end{array}$ & $\begin{array}{l}\text { Standard } \\
\text { deviation }\end{array}$ \\
\hline Present age & - & 46.5 years & 10.99 \\
\hline Age when started first business & - & 32.2 years & 8.89 \\
\hline Gender & $\begin{array}{l}\text { Male } \\
\text { Female }\end{array}$ & $\begin{array}{l}90 \% \\
10 \%\end{array}$ & $\begin{array}{l}- \\
-\end{array}$ \\
\hline Home language & $\begin{array}{l}\text { English } \\
\text { Afrikaans } \\
\text { Zulu } \\
\text { Xhosa } \\
\text { Other }\end{array}$ & $\begin{array}{c}86.1 \% \\
9.1 \% \\
1 \% \\
0.5 \% \\
3.4 \%\end{array}$ & $\begin{array}{l}- \\
- \\
- \\
-\end{array}$ \\
\hline Religion & $\begin{array}{l}\text { Christian } \\
\text { Hindu } \\
\text { Muslim } \\
\text { Jewish } \\
\text { Other }\end{array}$ & $\begin{array}{c}45.4 \% \\
43 \% \\
6.8 \% \\
1 \% \\
3.9 \%\end{array}$ & $\begin{array}{l}- \\
- \\
- \\
-\end{array}$ \\
\hline Race group & $\begin{array}{l}\text { Indian } \\
\text { White } \\
\text { Black } \\
\text { Coloured } \\
\text { Other }\end{array}$ & $\begin{array}{c}54.8 \% \\
39.5 \% \\
2.9 \% \\
2.4 \% \\
0.5 \%\end{array}$ & $\begin{array}{l}- \\
- \\
- \\
-\end{array}$ \\
\hline Position as child in family & $\begin{array}{c}\text { Eldest } \\
2^{\text {nd }} \text { eldest } \\
3^{\text {rd }} \text { eldest } \\
4^{\text {th }} \text { eldest } \\
5^{\text {th }} \text { eldest } \\
\text { Other }\end{array}$ & $\begin{array}{c}26.9 \% \\
26.4 \% \\
20.7 \% \\
9.6 \% \\
8.2 \% \\
8.2 \%\end{array}$ & $\begin{array}{l}- \\
- \\
- \\
- \\
-\end{array}$ \\
\hline Monthly income at age 18 & $\begin{array}{c}\mathrm{R} 0<\mathrm{R} 1,000 \\
\mathrm{R} 1,001<\mathrm{R} 5,000 \\
\mathrm{R} 5,001<\mathrm{R} 10,000 \\
\mathrm{R} 10,001<\mathrm{R} 20,000 \\
\mathrm{R} 20,001<\end{array}$ & $\begin{array}{c}37.3 \% \\
40.2 \% \\
14.2 \% \\
4.9 \% \\
3.4 \%\end{array}$ & $\begin{array}{l}- \\
- \\
- \\
-\end{array}$ \\
\hline Parents self-employed & $\begin{array}{l}\text { Father } \\
\text { Mother }\end{array}$ & $\begin{array}{l}22.9 \% \\
11.9 \%\end{array}$ & $\begin{array}{l}- \\
-\end{array}$ \\
\hline Role models & $\begin{array}{l}\text { No } \\
\text { Yes }\end{array}$ & $\begin{array}{c}60 \% \\
38.6 \%\end{array}$ & $\begin{array}{l}- \\
-\end{array}$ \\
\hline Risk profile & $\begin{array}{c}\text { Risk taker } \\
\text { Risk manager } \\
\text { Risk averter }\end{array}$ & $\begin{array}{c}44 \% \\
44.4 \% \\
11.6 \%\end{array}$ & $\begin{array}{l}- \\
- \\
-\end{array}$ \\
\hline $\begin{array}{l}\text { Age when introduced to } \\
\text { entrepreneurship }\end{array}$ & - & 24.8 years & 8.0 \\
\hline $\begin{array}{l}\text { Cultural attitude toward } \\
\text { entrepreneurship }\end{array}$ & $\begin{array}{c}\text { Conducive } \\
\text { Neutral } \\
\text { Negative }\end{array}$ & $\begin{array}{l}39.7 \% \\
44.5 \% \\
15.8 \%\end{array}$ & $\begin{array}{l}- \\
- \\
-\end{array}$ \\
\hline
\end{tabular}

Table 1: Means and frequency distributions of technological entrepreneurs 


\begin{tabular}{|l|c|c|c|l|}
\hline Independent variable & $\begin{array}{c}\text { Chi- } \\
\text { square }\end{array}$ & $\begin{array}{c}\text { Para- } \\
\text { meter }\end{array}$ & Probability & Dependent variable \\
\hline $\begin{array}{l}\text { Age when introduced to } \\
\text { entrepreneurship }\end{array}$ & - & 0.49 & 0.0001 & $\begin{array}{l}\text { Age when started } \\
\text { first new venture }\end{array}$ \\
\hline $\begin{array}{l}\text { Father and mother self- } \\
\text { employed }\end{array}$ & 4.26 & 0.74 & 0.0390 & Role model \\
\hline $\begin{array}{l}\text { Father and mother self- } \\
\text { employed }\end{array}$ & - & -4.55 & 0.0001 & $\begin{array}{l}\text { Age introduced to } \\
\text { entrepreneurship }\end{array}$ \\
\hline $\begin{array}{l}\text { Father and mother self- } \\
\text { employed }\end{array}$ & 7.10 & 1.09 & 0.0077 & $\begin{array}{l}\text { External private } \\
\text { financing }\end{array}$ \\
\hline $\begin{array}{l}\text { Family income at } 18 \\
\text { years }\end{array}$ & 2.37 & 0.54 & 0.0254 & $\begin{array}{l}\text { External commercial } \\
\text { financing }\end{array}$ \\
\hline $\begin{array}{l}\text { Father and mother self- } \\
\text { employed }\end{array}$ & 5.00 & 7.01 & 0.0254 & $\begin{array}{l}\text { Business incubator } \\
\text { assistance during } \\
\text { start-up }\end{array}$ \\
\hline
\end{tabular}

Table 2: Correlations with growing-up heritage variables

\begin{tabular}{|c|c|c|c|c|}
\hline Independent variable & $\begin{array}{l}\text { Chi- } \\
\text { square }\end{array}$ & $\begin{array}{l}\text { Para- } \\
\text { meter }\end{array}$ & Probability & $\begin{array}{l}\text { Dependent } \\
\text { variable }\end{array}$ \\
\hline $\begin{array}{l}\text { Attitude of culture } \\
\text { towards entrepreneurship }\end{array}$ & 4.72 & -0.52 & 0.0299 & Role model \\
\hline Indian race & - & -0.44 & 0.0328 & Risk profile \\
\hline $\begin{array}{l}\text { Attitude of culture } \\
\text { towards entrepreneurship }\end{array}$ & - & 0.22 & 0.0403 & Technology transfer \\
\hline Hindu religion & 5.87 & -0.89 & 0.0154 & Founder financing \\
\hline White race & 5.72 & -0.92 & 0.0168 & $\begin{array}{l}\text { External private } \\
\text { financing }\end{array}$ \\
\hline Language & 5.04 & -1.27 & 0.0248 & $\begin{array}{l}\text { External private } \\
\text { financing }\end{array}$ \\
\hline $\begin{array}{l}\text { Attitude of culture } \\
\text { towards entrepreneurship }\end{array}$ & 4.45 & -1.24 & 0.0349 & $\begin{array}{l}\text { Previous employer } \\
\text { assistance during } \\
\text { start-up }\end{array}$ \\
\hline Language & 4.18 & 2.69 & 0.0409 & $\begin{array}{l}\text { Private sector } \\
\text { assistance during } \\
\text { start-up }\end{array}$ \\
\hline $\begin{array}{l}\text { Attitude of culture } \\
\text { towards entrepreneurship }\end{array}$ & 4.08 & 0.72 & 0.0434 & $\begin{array}{l}\text { Business failures } \\
\text { reported }\end{array}$ \\
\hline Hindu religion & 3.96 & -1.23 & 0.0466 & $\begin{array}{l}\text { Business failures } \\
\text { reported }\end{array}$ \\
\hline Indian race & 4.74 & -1.65 & 0.0294 & $\begin{array}{l}\text { Government } \\
\text { contracts at present }\end{array}$ \\
\hline
\end{tabular}

Table 3: Correlations with cultural heritage variables 
at the age of 18. Six dependent variables showed significant correlations (in order of lowest to highest probability) with the independent variables. They are: 1) age when first business was started, 2) age when first introduced to entrepreneurship, 3) external private financing, 4) external commercial financing, 5) business incubator assistance during start-up, and 6) entrepreneurial role model. Detailed results of the analysis are given in Table 2.

The analysis also indicated five independent variables classified as cultural heritage. They are: 1) the cultural attitude towards entrepreneurship, 2) \& 3) race groups (Indian and white), 4) Hindu religion, and 5) home language. The nine correlating dependent variables (in order of lowest to highest probability) are: 1) extent of founder's financing, 2) external private financing, 3) percentage of government contracts at present, 4) entrepreneurial role model, 5) risk profile, 6) previous employer assistance during start-up, 7) degree of technology transfer, 8) private sector assistance during start-up, and 9) previous business failures reported. Detailed results of the analysis are given in Table 3.

\subsection{Discussion}

\subsubsection{The survey sample profile}

The profile of the survey sample reveals significant information that acts as background for result interpretation, and enables comparison with other studies. A summary of the profile follows:

The survey sample consists predominantly of male, English-speaking entrepreneurs in their mid-forties who started their first business in their early thirties. They come from two dominant race (Indian and white) and religion groups (Christian and Hindu). They have no particular order as a child in the family; come from low- to medium-income households where about one third of the parents were self-employed. The majority of them did not have an entrepreneurial role model; they classify themselves as risk takers or risk managers rather than risk averter; and were only introduced to the concept of entrepreneurship at about the age of 25 years. They regard the view towards entrepreneurship of the culture group in which they grew up as mainly neutral or conducive to entrepreneurship.

\subsubsection{Significant relationships: growing-up heritage}

The self-employed status of the parents emerges as a strong independent influence on several entrepreneurial traits as well as the new venture creation process. Four relationships are identified:

- The first significant relationship indicates that entrepreneurs with selfemployed parents tend to be introduced to entrepreneurship at an earlier age than those with parents that are not self-employed. This confirms the logical conclusion that the child is exposed to entrepreneurship at an earlier age through the parents' example, compared to those with non-entrepreneurial parents. 
- $\quad$ The second strong relationship indicates that when external financing (versus financing with the founder's money) is done during the new venture creation process, entrepreneurs with self-employed parents tend to make more use of commercial financing (banks and other financing institutions) and less use of funds from private individuals such as friends, family, or 'angels'. One can draw the conclusion that the exposure to the self-employment environment induced a confidence in the young entrepreneur to obtain funding from 'foreign' financing organizations in a professional manner, rather than the comfortable zone of family and friends.

- $\quad$ A small percentage (4.8\%) of respondents received assistance from a business incubator during their start-up process. Entrepreneurs with self-employed parents tend to dominate this group, which also confirms the notion that selfconfidence to be assisted professionally was strengthened in young entrepreneurs during their growing-up experience in an entrepreneurial home.

- Lastly, entrepreneurs who come from homes where the parents were selfemployed tend to have fewer role models than those whose parents were not self-employed. This tendency could be explained from the viewpoint that the self-employed parents satisfied the (potential) need for an entrepreneurial role model.

Another strong correlation in the growing-up experience group indicates that entrepreneurs who are introduced to entrepreneurship at a younger age tend to start new ventures at an earlier age. This relationship confirms the logical conclusion that knowledge about the concept of entrepreneurship at an early age helps entrepreneurs to gain confidence to start their own business sooner.

The last significant relationship addresses the influence of family income on the financing pattern during start-up of the new venture: entrepreneurs from lower income families tend to finance their businesses through external commercial entities rather than through private sources. This tendency is perhaps the result of a lack of wealthy family or friends, or an early drive to be self-sufficient in the business world.

\subsubsection{Significant relationships: cultural heritage}

In the cultural heritage domain, the attitude of the society or culture in which the entrepreneur grew up towards entrepreneurship plays a significant role on entrepreneurial behaviour during the new venture creation process and in the established or mature business. These influences are:

- $\quad$ Societies that are conducive to entrepreneurship tend to influence positively the practice of having role models and the direct transfer of technology from previous employers to the new venture.

- The same conducive societies tend to influence negatively the assistance received from previous employers during the start-up phase, as well as the number of previous business failures which entrepreneurs reported. The latter 
tendency is not necessarily negative, in the sense that a business failure is not always seen as a failure, but as a learning experience.

Language as a cultural aspect tends to influence the nature of external financing that entrepreneurs utilize during start-up: English-speaking respondents reported more financing through friends and family than entrepreneurs from other languages. Conversely, non-English speaking respondents reported more assistance from the private sector than English speaking entrepreneurs during the start-up.

Race and religion are also important environmental influences on entrepreneurial behaviour: Indian respondents tend to be greater risk takers than those from other race groups, and businesses managed by them tend to have fewer government contracts than those managed by other race groups; when external financing is done (other than from the founder's funds) white entrepreneurs tend to use more private funding than entrepreneurs from other race groups; entrepreneurs from the Hindu religion reported more business failures and finance their new ventures more from external funds (other than their own) than their counterparts from other religions.

\subsubsection{Model presentation}

The relationships described above were derived from the results obtained during stepwise multiple regression analyses and model fitting performed on 25,000 data points and several sets of independent and dependent variables. The relationships discussed here are part of this larger study, but only those independent variables classified as heritage factors were grouped in cultural and growing-up influences on the overall entrepreneurship process. The implication of using this method as a statistical technique is that the correlation results are less significant as individual relationships, but should rather be seen in the context of batches of variables grouped together to form a relationship with a single dependent variable. The results can also be represented in model format, consisting of the technological entrepreneurship domain (with 13 dependent variables) and the two heritage related influences (with 8 independent variables). This model is shown in Figure 3.

The equation for multiple regression with $\mathrm{k}$ independent variables is [16]:

$Y^{\prime}=a+b 1 X 1+b 2 X 2+b 3 X 3+------+b k X k$

Where:

$Y$, read $Y$ prime, is the predicted value of the $Y$ dependent variable for a selected $X$ value;

$a \quad$ is the $Y$-intercept. It is the estimated value of $Y$ when $\mathrm{X}=0$;

$b \quad$ is the slope of the line, or the parameter or the average change in $Y$ ' for each change of one unit (either increase or decrease) in the independent variable $X$; and

$X \quad$ is any value of the independent variable that is selected.

In this model, technological entrepreneurship is presented by the equations: 
$E t=f 1+f 2$

$f 1=Y^{\prime} 1+Y^{\prime} 2+Y^{\prime} 3+Y^{\prime} 4$

$f 2=Y^{\prime} 5+Y^{\prime} 6+\ldots \ldots+Y^{\prime} 12+Y^{\prime} 13$

Where:

Et is technological entrepreneurship;

$f 1 \quad$ is the growing-up heritage influences;

f2 is the cultural heritage influences;

$Y^{\prime} 1$ to $Y^{\prime} 4$ are the four dependent variables classified as growing-up heritage; and $Y^{\prime} 5$ to Y'13 are the nine dependent variables classified as cultural heritage.

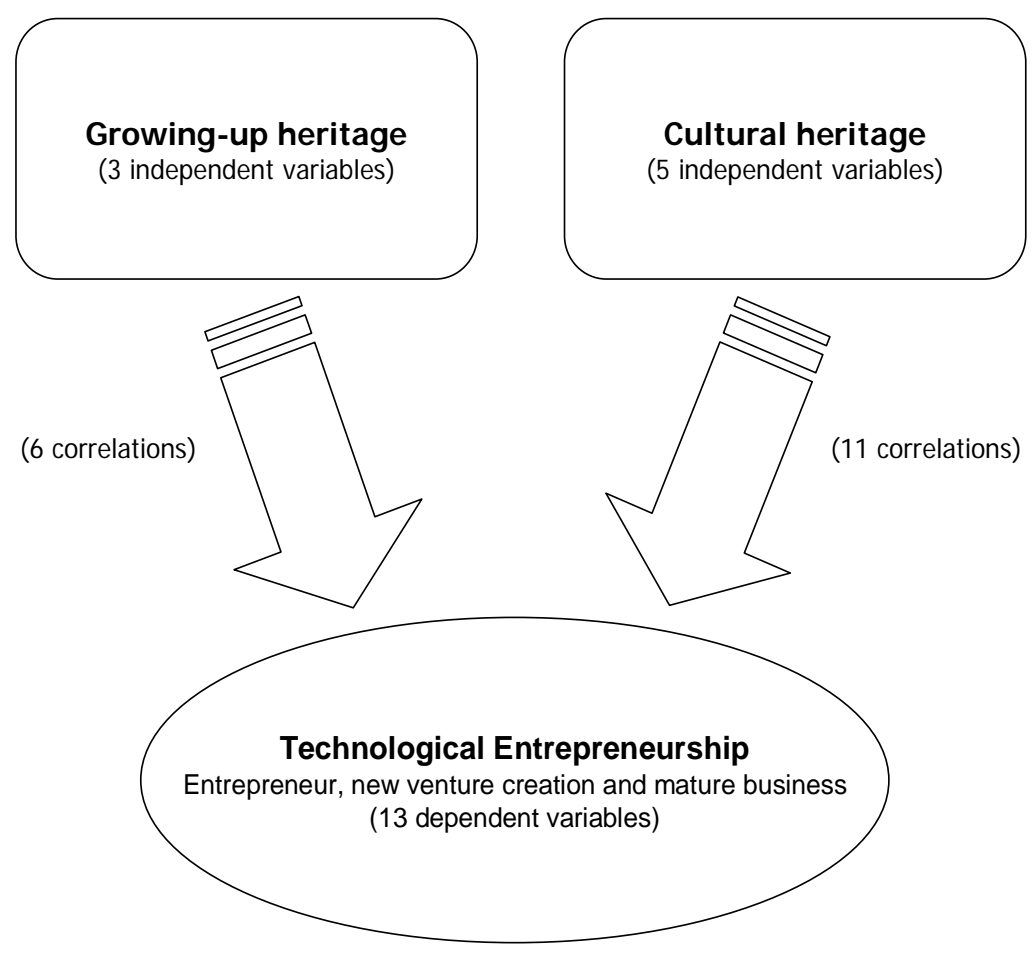

Figure 3: Model presentation of heritage influences on technological entrepreneurship

\subsubsection{Validity of model}

The validity of the individual models for each dependent variable in the larger study was tested by measuring the adjusted R-square values for linear regression fitting and maximum rescaled $\mathrm{R}$-square values for logistic regression fitting.

These values for the thirteen dependent variables defining the technological entrepreneurship domain in the heritage influence model are given in Table 4. An Rsquare value of 0 indicates that there is no model fit of the defined variables, while a 1.0 value indicates a perfect model fit. 


\begin{tabular}{|l|c|c|c|}
\hline Individual models (dependent variables) & $\begin{array}{c}\text { Survey } \\
\text { sample } \\
\text { frequency }\end{array}$ & $\begin{array}{c}\text { Adjusted } \\
\text { R-square }\end{array}$ & $\begin{array}{c}\text { Max } \\
\text { rescaled } \\
\text { R-square }\end{array}$ \\
\hline Linear regression & 192 & 0.4549 & - \\
\hline Age when started first new venture & 201 & 0.2142 & - \\
\hline Age introduced to entrepreneurship & 200 & 0.0595 & - \\
\hline Risk profile & 188 & 0.1782 & - \\
\hline Technology transfer & & & \\
\hline Logistic regression & 204 & - & 0.1441 \\
\hline Role model & 106 & - & 0.2161 \\
\hline External private financing & 100 & - & 0.1418 \\
\hline External commercial financing & 45 & - & 0.5729 \\
\hline Business incubator assistance during start-up & 115 & - & 0.1722 \\
\hline Founder financing & 44 & - & 0.1748 \\
\hline Previous employer assistance during start-up & 41 & - & 0.4538 \\
\hline Private sector assistance during start-up & 170 & - & 0.1852 \\
\hline Business failures reported & 190 & - & 0.1261 \\
\hline Government contracts at present
\end{tabular}

Table 4: Adjusted R-square and maximum rescaled R-square values

The degree of model fit as indicated by the R-square values of Table 4 is as expected for a population of this diverse and non-homogenous nature. Only one R-square value is lower than 0.1 (risk profile) with the highest values being 0.5729 and 0.4549 , which indicate a relatively good fit for the heritage influence model.

\section{CONCLUSION}

\subsection{Comparison with other studies}

\subsubsection{First born issue}

The results clearly indicate that there is no dominant order in the person's position as a child in the family. Roughly one quarter of the respondents were the first-, secondor third-born child in their families. No significant relationship between the position as a child in the family (predictor) and any dependent variable could be found.

- $\quad$ This supports the findings of Roberts [5] that first-born children are not more likely than their siblings to become high-technology entrepreneurs.

- $\quad$ It does not support the findings of Henning et al [9] and Brockhaus et al [3] that entrepreneurs tend to be the oldest child in the family.

\subsubsection{Self-employment status of parents}

Only one third of the respondents come from families where either the mother or father was self-employed. The influence of the parents' status on the entrepreneurial 
behaviour of respondents is strongly reflected in the numerous relationships that emanated from the regression analyses.

- It supports the findings of Roberts [5] that entrepreneurs are very likely to have self-employed fathers;

- $\quad$ It also supports the view of Hisrich et al [2] that having self-employed parents provides a strong inspiration for the entrepreneur.

\subsection{Does heritage matter?}

The study revealed that environmental heritage, both in terms of growing-up experiences and cultural aspects, does have an influence on the entrepreneurial behaviour of technological entrepreneurs in emerging societies. This finding is true as far as the environmental influences on the development of the entrepreneur are concerned. These influences are home language, religion, age when first introduced to entrepreneurship, attitude of society towards entrepreneurship, self-employment status of parents, and family income at the age of 18 years.

No evidence was found that genetic inheritance such as race and gender has any direct influence on entrepreneurial behaviour. Where race features in certain relationships, they are all environmentally related cases where the dependent variables are dictated by cultural or societal views - for example, where race is a factor in the award of government contracts, or influences the nature of funding sources during start-up. In these cases race should be classified as an environmental heritage rather than a genetic heritage. The black technological entrepreneurs in the survey sample constitute a small minority (5.7\%). This is somewhat surprising, especially when compared to the findings of the South African Global Entrepreneurship Monitor (GEM) survey of 2004 [17] that black entrepreneurs make up a large portion (77.2\%) of the total population of all entrepreneurs. This discrepancy can be attributed to the fact that the GEM statistics indicate total selfemployment per race group, which includes all types of business categories (such as street vendors) in the informal sector of the economy. Our survey sample consists of technological entrepreneurs only. The logical conclusion is that black entrepreneurs in the Province studied are mostly involved in other than technological types of enterprises.

In conclusion, the study supports the views of Roberts [5], Drucker [6] and Timmons et al [4] that, while certain entrepreneurial personality traits are associated with successful entrepreneurs, environmental influences such as cultural and growing-up heritage contribute significantly to the 'making' of technological entrepreneurs. It also supports the view of Wickham [1] that the process of entrepreneurship is fundamentally universal for all communities, and that a multi-cultural and economically emerging society only influences the 'surface veneer'.

\subsection{Policy implications}

Two prominent aspects emerged from the research that decision makers in South 
Africa and other emerging regions could utilize during policy and strategy formulations. They are:

- The importance is highlighted of cultural influences such as race group, language, religion, and society's view of entrepreneurship in the development process of the technological entrepreneur, and on his or her success in the new venture creation process, as well as further growth to a mature business. These influences are supported by the strong and numerous correlations found during the model building process.

- The effect of the South African government's black empowerment policies and efforts over the past ten years to assist new enterprise formation have not benefited all entrepreneurs in the technology domain that are classified as being disadvantaged by the apartheid legacy. Despite being the majority of respondents (55\%), the fact that Indian entrepreneurs receive fewer government contracts than entrepreneurs from other race groups confirms this. In addition, the poor representation of black (that is, not white or Indian) founders $(5.7 \%)$ of new technological enterprises does not reflect the racial composition of the sample society's self-employment profile for all types of enterprises (77.2\%).

\subsection{Future research areas}

The specific influences of the following two aspects on technological entrepreneurship in multi-cultural and economically emerging societies have been identified as future research areas:

- $\quad$ The embedded views of various cultural groups on the concept and practices of entrepreneurship, specifically in the technological domain.

- $\quad$ The embedded views of various religions on the concept of entrepreneurship, specifically in the technological domain.

The research areas above should be approached with concepts and techniques from cognitive science that have gained currency within the entrepreneurship research domain, as propagated by Mitchell et al [18].

This material is based upon work supported by the National Research Foundation under Grant number GUN2053330. Any opinion, findings and conclusions or recommendations expressed in this material are those of the authors and do not necessarily reflect the views of the National Research Foundation.

\section{REFERENCES}

[1] Wickham, P.A. 2004. Strategic Entrepreneurship, Third edition, FT Prentice Hall, Essex, England.

[2] Hisrich, R.D., Peters, M.P. and Shepherd, D.A. 2005. Entrepreneurship, Sixth Edition, McGraw Hill/Irwin, New York. 
[3] Timmons, J.A. and Spinelli, S. 2004. New Venture Creation: Entrepreneurship for the $21^{\text {st }}$ Century, Sixth Edition, McGraw Hill/Irwin, New York.

[4] Roberts, E.B. 1991. Entrepreneurs in high technology. Lessons from MIT and beyond, Oxford University Press, Cambridge.

[5] Bolton, W.K. and Thompson, J.L. 2000. Entrepreneurs: Talent, Temperament, Technique, Butterworth-Heinemann, Oxford, UK.

[6] Drucker, P. F. 2001. Innovation and Entrepreneurship, ButterworthHeinemann, Oxford.

[7] Kuratko, D.F. and Hodgetts, R.M. 1998. Entrepreneurship: A Contemporary Approach, Fourth Edition, Dryden Press, Fort Worth, USA.

[8] Hornsby, J.S. and Kuratko, D.F. 2002. The human resource function in emerging enterprises, South-Western/Thomson Learning, Mason, Ohio.

[9] Rwigema, H. and Venter, R. 2004. Advanced Entrepreneurship, Oxford University Press Southern Africa, Cape Town.

[10] Marlow, S. and Patton, D. 2005. All credit to men? Entrepreneurship, Finance and Gender, Entrepreneurship Theory and Practice, 11, pp 717-735.

[11] Nieuwenhuizen, C. 2004. The nature and development of entrepreneurship, In Entrepreneurship: A South African Perspective (Nieman, G., Hough, J. and Nieuwenhuizen, C. Eds.), Van Schaik Publishers, Pretoria.

[12] Verheul, I., Van Stel, A. and Thurik, R. 2006. Explaining female and male entrepreneurship at the country level, Entrepreurship \& Regional Development, 18(2), pp 151-183.

[13] Zafirovski, M. 1999. Probing into the social layers of entrepreneurship: outlines of the sociology of enterprise, Entrepreneurship \& Regional Development, 11, pp 351-371.

[14] Frederking, L.C. 2004. A cross-national study of culture, organization and entrepreneurship in three neighbourhoods, Entrepreneurship \& Regional Development, 16(3), pp 197-215.

[15] Braby's electronic database. 2002. Durban, South Africa, CD disk, Version 1.2, September 2004.

[16] Lind, D.A., Marchal, W.G. and Mason, R.D. 2002. Statistical Techniques in Business \& Economics, Eleventh Edition, McGraw Hill, New York.

[17] Orford, J., Herrington, M. and Wood, E. 2004. Global Entrepreneurship Monitor, Graduate School of Business, University of Cape Town, Cape Town.

[18] Mitchell, R.K., Busenitz, L., Lant, T., McDougall, P.P., Morse, E.A. and Smith, J.B. 2002. Toward a Theory of Entrepreneurial Cognition: Rethinking the People Side of Entrepreneurship Research, Entrepreneurship Theory \& Practice, Winter, pp 93-104. 